\title{
Russian guidelines for the management of COPD: algorithm of pharmacologic treatment [Corrigendum]
}

Aisanov Z, Avdeev S, Arkhipov V, Belevskiy A, Chuchalin A, Leshchenko I, Ovcharenko S, Shmelev E, Miravitlles M. Int J Chron Obstruct Pulmon Dis. 2018;13:183-187.

Page 186, Disclosure, the text "The authors report no conflicts of interest in this work" should read "SA has received speaker/consultancy fees from Boehringer Ingelheim, AstraZeneca, Chiesi, Teva and Novartis; non-financial support from Boehringer Ingelheim, Chiesi and Novartis; and research grants from AstraZeneca, GlaxoSmithKline and Novartis. MM has received speaker fees from Boehringer Ingelheim, Chiesi, Cipla, Menarini, Rovi, Bial, CSL Behring,
Grifols and Novartis; consultancy fees from Boehringer Ingelheim, Chiesi, GlaxoSmithKline, Bial, Gebro Pharma, CSL Behring, Laboratories Esteve, Mereo BioPharm, Verona Pharma, pH Pharma, Novartis and Grifols; and research grants from GlaxoSmithKline and Grifols. ZA has received speaker/ consultancy fees from Boehringer Ingelheim, AstraZeneca, Chiesi, Teva and Novartis, GlaxoSmithKline; non-financial support from Boehringer Ingelheim, GSK and Novartis; and research grants from AstraZeneca, GlaxoSmithKline and Novartis. The authors report no other conflicts of interest in this work".
International Journal of COPD

\section{Publish your work in this journal}

The International Journal of COPD is an international, peer-reviewed journal of therapeutics and pharmacology focusing on concise rapid reporting of clinical studies and reviews in COPD. Special focus is given to the pathophysiological processes underlying the disease, intervention programs, patient focused education, and self management protocols.

\section{Dovepress}

This journal is indexed on PubMed Central, MedLine and CAS. The manuscript management system is completely online and includes a very quick and fair peer-review system, which is all easy to use. Visit http://www.dovepress.com/testimonials.php to read real quotes from published authors. 